\title{
Vole Damage to Coniferous Trees on Texada Island
}

\author{
by
}

Paula A. Harper and Alton S. Harestad ${ }^{1}$

\begin{abstract}
On Texada Island, British Columbia, Townsend voles injured trees by removal of bark and cambium from stems, branches, and roots of Douglas-fir, western hemlock, and, rarely, western white pine. Damage occurred more frequently in pre-commercially thinned stands less than 40 years of age than in unspaced stands. Within these stands there was no selection by voles for age or diameter. However, damage increased with decreasing height. Two years after damage and spacing, injured trees exhibited no measurable reductions in volume of annual growth, and hence control of voles is not recommended. Monitoring of the damaged areas should be continued and potential long term effects evaluated.
\end{abstract}

Key Words: British Columbia, debarking, Microtus townsendii, thinning, voles, wildlife damage.

\section{Résumé}

Sur l'île de Texada, Colombie Britannique, les mulots de Townsend ont causé des dommages aux arbres en grugeant l'écorce et le cambium des tiges, des branches et des racines du sapin Douglas, de la pruche de l'Ouest et à quelques occasions du pin blanc de l'Ouest. Les dommages se sont avérés être plus fréquents dans les peuplements de moins de quarante ans ayant subis une éclaircie de dégagement que dans les peuplements non dégagés. Les mulots n'ont fait aucune distinction dans ces peuplements en terme d'âge ou de diamètre. Toutefois, les dommages ont augmenté en proportion inverse de la hauteur. Deux années après les dommages et le dégagement, les arbres attaqués n'ont pas démontré de réduction mesurable en terme d'accroissement annuel en volume, et par le fait même aucune méthode de contrôle des mulots n'est recommandée. La surveillance des zones affectées devrait se poursuivre et les effets potentiels à long terme devraient être évalués.

\section{Introduction}

By their feeding activities, mammalian pests may kill trees, retard stand establishment, affect growth rates, and increase a tree's susceptibility to decay and insects (Canutt 1969, Campbell 1976. Sullivan 1984). Damage by small mammals, apparently Townsend voles (Microtus townsendii [Bachman]), has been reported on Vancouver Island in the Malksope Inlet, Port Renfrew, and Cowichan Lake areas. Trees in 5- to 10-year-old naturally regenerated stands of western hemlock, Tsuga heterophylla (Raf.) Sarg., have been severely debarked as have seedlings and trees in 4- to 6year-old plantations of grand fir, Abies grandis (Dougl.) Lindl. (F. Hamre, pers. comm.; D. McMullen, pers. comm.).

On Texada Island, Townsend voles debarked young trees in spaced (pre-commercially thinned) plantations of Douglas-fir, Pseudotsuga menzieii (Mirb.) Franco (Howard 1982). Elsewhere on the island, spaced, natural stands of Douglas-fir have also been damaged by voles. Our objectives were to: document features of trees and stands receiving intensive vole damage; determine the extent of vole damage on Texada Island, and evaluate the desirability of implementing a control program.

\footnotetext{
Centre for Pest Management. Department of Biological Sciences, Simon
} Fraser University, Burnaby, B.C. V5A 1 S6.

\section{Methods}

Texada Island is $8 \mathrm{~km}$ southwest of Powell River and lies within three biogeoclimatic subzones: the Drier Maritime Coastal Western Hemlock, the Drier Maritime Coastal Douglas-fir, and the Wetter Maritime Coastal Douglas-fir subzones (Klinka et al. 1979). To document features of trees and stands receiving intensive damage by voles, six stands were examined in the Long Beach area approximately $30 \mathrm{~km}$ southeast of Vananda. These stands were in the Wetter Maritime Coastal Douglas-fir subzone and between 100 and $350 \mathrm{~m}$ in elevation. Three stands (A, D, F) were spaced in early 1982 and three other stands (A', D'. F') of corresponding aqe and site characteristics were unspaced (Fig. 1).

All stands were naturally regenerated with Douglas-fir as the dominant species. The stands ranged in age from 8-33 years; in height from $3-18 \mathrm{~m}$; in mean diameter at breast height $(\mathrm{DBH})$ from 2-14 cm; and in slash level from low to high. For spaced stands, A, D, and F, there were 1200,1225 and 625 stems/ha respectively; whereas for unspaced stands, $A^{\prime}, D^{\prime}$, and $F^{\prime}$, there were 10600,10700 and 15500 stems/ha respectively. Each of the three unspaced stands was similar to its paired, spaced stand but no site evaluations were available. Except for mosses and lichens, stand F had little understory vegetation, possibly due to a thick layer of slash remaining after thinning. 


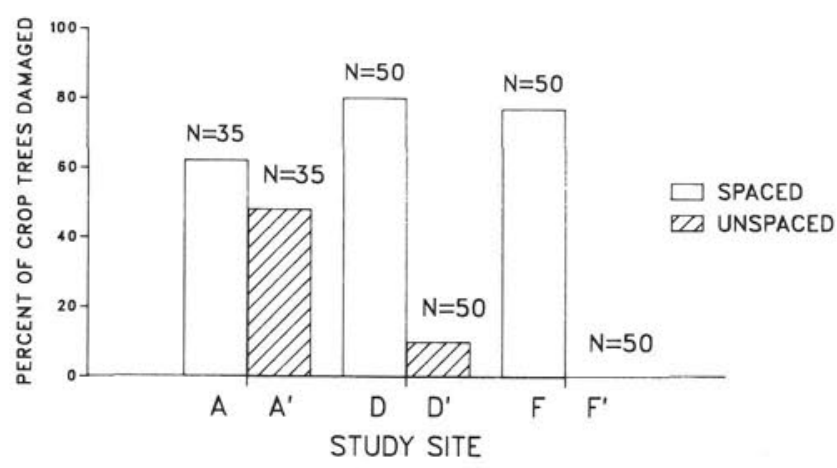

Figure 1. Vole damage in spaced and unspaced stands. Differences in damage between stands $\mathrm{D}$ and $\mathrm{D}^{\prime}$ and $\mathrm{F}$ and $\mathrm{F}^{\prime}$ are significant $\left(\chi^{2}=\right.$ $58.4,44.0, \mathrm{df}=2, \mathrm{p} \leq 0.05$ ).

For each stand, all trees were measured and damage assessed in circular plots ( 4 m radius) established every 25 or $50 \mathrm{~m}$ on a $400 \mathrm{~m}$ transect depending on the size of the stand. Transects were systematically located along the length of the stand. In each stand, 35 to 50 stems were assessed. The severity of damage was determined by measuring the percentage of the tree's circumference at the base from which bark was removed. The trees were assigned to the following injury classes in terms of percentage of circumference debarked: $0 \%$ (undamaged), 1-25\% (low), 26-70\% (moderate), or $>70 \%$ (severe). The condition of each tree was noted as leaning, dying, chlorotic (yellow foliage, shedding leaves), weak, or no observable symptoms. Tree height, $\mathrm{DBH}$, maximum length and width of wound, and circumference of the tree at each wound, were recorded. Besides stands, A, D, and $F$, four additional spaced stands were sampled to obtain a broader representation of damaged trees. Between 9 and 19 circular plots were sampled in each stand. For the total of 84 plots, 587 trees were assessed.

The dispersion of damage in stands, A, D and $F$ was determined from belt transects $(1 \times 100 \mathrm{~m})$ extending from the center of each study site into the surrounding stand. Every Dougals-fir tree within the $1 \mathrm{~m}$ belt was assessed for damage.

To determine the extent of vole damage on Texada Island, 67 spaced stands were assessed at Long Beach, Poncahontas Bay, Anderson Bay, and Cook Bay. Spot checks were conducted in each spaced block and the percentage of debarking was determined for at least 100 trees.

The impact of damage on tree growth was examined to determine whether control of voles was warranted. Forty Douglas-fir trees (mean age 27 years) were felled and the incremental height and basal radial growth of each was measured at stump height to determine the impact of vole damage on tree growth. Ten of the trees were in an unspaced stand and undamaged. The remaining 30 trees were in a spaced stand: 10 were undamaged, 10 moderately damaged and 10 were severely damaged. The incremental volume was calculated by: Volume $=($ Basal Area $) \times($ Height $)$. Calculations accounting for taper were also made and gave similar results. Volume measurements were converted to a growth percentage (Avery 1967) for two years prior to spacing and vole damage (1980-1981) and compared with the growth percentage for the two years following these events (19821983). Signs of injury first occurred in winter 1981-1982, and that appeared to be the year of greatest vole damage.

\section{Results}

Features of the trees and stands damaged by voles were examined. Observations of debarking scars on damaged trees, the occurrence of runways through low vegetation, and trap captures revealed that the Townsend vole was the species damaging trees. Damage consisted of injuries to the bark and cambium of stems, branches and roots of Douglasfir, western hemlock, and rarely western white pine, Pinus monticola Dougl. Usually the stem collar was debarked to about $15 \mathrm{~cm}$ above ground, but occasionally low branches allowed voles to climb and debark higher on the stem. The severity of damage was not correlated with condition of the tree $\left(r_{S}=0.21, n=144, p>0.05\right)$. Some trees that were completely girdled showed no observable symptoms of damage, whereas others that were $<10 \%$ debarked appeared chlorotic. In two of the three paired stands, there was a significantly greater incidence of damage in the spaced stands than in the unspaced stands (Fig. 1).

The height of trees examined in the study sites ranged from 0.8 to $18.1 \mathrm{~m}$. No trees taller than $16 \mathrm{~m}$ were damaged by voles. For trees less than $16 \mathrm{~m}$, incidence of damage increased significantly with decreasing height $\left(\chi^{2}=16.2\right.$, $d f=6, p \leq 0.05$ ) (Fig. 2). However, the severity of damage, although significantly different among height classes, showed no strong trend. Trees with diameters up to $19 \mathrm{~cm} \mathrm{DBH}$ were damaged by voles. Damage to trees was examined in diameter classes $0-4,5-8,9-12,13-16$, and $17-19 \mathrm{~cm}$. The proportion of trees injured did not differ among the $\mathrm{DBH}$ classes $\left(\chi^{2}=13.8, d f=8, p>0.05\right)$, indicating that Townsend voles did not feed on specific sizes of trees within this $\mathrm{DBH}$ range. Severity of vole damage was similar in three stands of different ages indicating that within this age range $(8$ to 33 years) there was no selection for tree age $\left(\chi^{2}=3.1\right.$, $\mathrm{df}=8$, $p>0.05)$.

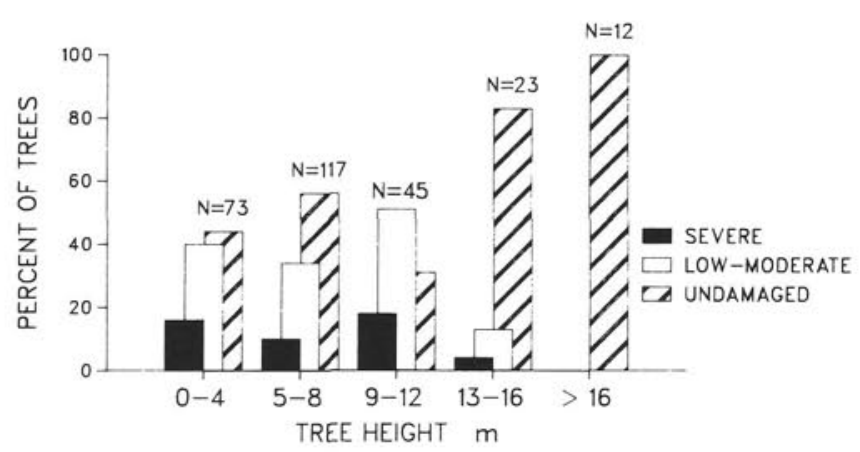

Figure 2. Severity of vole damage and tree height in stands of Douglas-fir. 
The total incidence and severity of damage did not decline significantly with distance from the center of study sites $A$ and $F$, but did decline at site $D\left(\chi^{2}=23.3\right.$, df $=2$, $p \leq 0.05$ ). Therefore, it appears that the amount of damage in stands $A$ and $F$ was representative of the entire stand of trees whereas site $D$ represented a small pocket of severe vole damage relative to the entire stand. Decreased damage near the edge of site $D$ could result from habitat changes at the stand boundary near a buffer strip of unspaced trees.

Other stands were examined to determine the extent of vole damage on Texada Island. Douglas-fir and western hemlock were damaged with equal frequency in the Long Beach area. Damage to western hemlock occurred as localized pockets in spaced stands at Pocahontas Bay, Anderson Bay, and Cook Bay. In these stands Douglas-fir were not damaged indicating that voles preferred western hemlock to Douglas-fir. The spot checks indicated minor damage by voles occurred in most spaced stands on the island, although there were centres of severe damage.

Growth rates of trees were measured to determine whether control of voles was warranted. There were no signficant differences in growth rates of trees damaged at any level by voles when comparing the 2-year average before spacing and vole damage with the average after these events (Table 1). This apparent lack of an adverse effect must be treated cautiously since the impact of injury on growth may not be apparent for several years. Correspondingly, the beneficial effect of spacing on growth of undamaged trees also had not become evident.

\section{Discussion}

The greater incidence of debarking by voles in spaced stands may have occurred because of the increased vigor of spaced trees. This damage may also have resulted from increased amounts of cover and, in some cases, decreased amounts of food in spaced stands. Spacing leaves various amounts of slash depending upon the type of thinning and age of trees. In some areas on Texada Island, where 25- to 35year-old Douglas-fir stands were spaced, a thick layer of slash was on the ground. This slash provided cover for voles which may reduce their mortality due to predation (Birney et al. 1976), intraspecific aggression (Warnock 1965), and harsh winter weather. Besides reducing mortality, the slash may also allow more activity during the day thereby increasing time available to voles for foraging. In these forest habitats, food normally used by voles is reduced because the accumulated slash inhibits forage production (USDA Forest Service 1968). Green (1978) concluded that debarking by small mammals indicates nutritional stress. It appears then, that the Townsend vole was debarking conifers for food because preferred vegetation was scarce.

Vole damage is positively correlated with high population densities of voles (Buckner 1972, Green 1982) and with ideal habitat conditions (Dimock 1971, Martell and Radvanyi 1976). Cyclic fluctuations in populations of various vole species occur roughly every 3 to 4 years in northern latitudes (Krebs 1979). Krebs (1979) also reported that populations of Townsend voles near Vancouver, B.C. do not exhibit 3- to 4year cycles but fluctuate in annual or occasional irruptions. On Texada Island, voles were at low densities in the Long Beach area during spring 1984. Because of these low densities, damage was probably not the result of a population irruption. Damage more likely occurred because of the increased cover and favourable bark condition of the spaced trees.
Table 1. Average growth rates of Douglas-fir trees with various amounts of vole damage.

\begin{tabular}{lrrrr}
\hline \multirow{2}{*}{$\begin{array}{l}\text { Damage class and } \\
\text { stand condition }\end{array}$} & \multicolumn{4}{c}{ Average growth rate (\%) \pm SE } \\
\cline { 3 - 4 } & N & $\mathbf{1 9 8 0 - 1 9 8 1}$ & $\mathbf{1 9 8 2 - 1 9 8 3}$ & U \\
\hline Undamaged, unspaced & 10 & $5.0 \pm 0.6$ & $5.3 \pm 0.5$ & 45 \\
Undamaged, spaced $^{3}$ & 10 & $20.0 \pm 1.2$ & $20.5 \pm 1.9$ & 474 \\
Moderate, spaced $^{3}$ & 10 & $24.1 \pm 1.2$ & $22.9 \pm 0.7$ & $45^{4}$ \\
Severe, spaced $^{3}$ & 10 & $22.3 \pm 3.3$ & $20.5 \pm 1.2$ & $47^{4}$ \\
\hline
\end{tabular}

2Most injuries occurred in winter 1981-1982.

3Spacing occurred in 1982

${ }^{4}$ No significant differences $(p>0.05)$ between growth rates before and after spacing and damage (Mann-Whitney $U$ test)

Trees up to $16 \mathrm{~m}$ in height and $19 \mathrm{~cm}$ in $\mathrm{DBH}$ were susceptible to vole damage. Below these size thresholds, the severity of damage was not strongly associated with any particular size of tree. Stands of trees up to 40 years of age were damaged with equal frequency by voles. This range of susceptible ages is important when considering implications of vole damage to forestry. Where damage is economically important, small, young trees may need protection until they grow beyond the susceptible ages and sizes.

The Townsend vole is not currently causing a significant impact on forest regeneration or productivity on Texada Island. This assessment is based on the distribution of damage, tree species preference, and growth estimates. Damage in spaced stands within the susceptible age range was not extensive on Texada Island. There were pockets of localized damage on Douglas-fir only in the Long Beach area, whereas, low to moderate damage on western hemlock existed in at least one spaced block at Pocahontas Bay, Anderson Bay and Cook Bay. In these areas on Texada Island, voles prefer western hemlock over Douglas-fir. Their damage is not of prime concern because it is not directed at the desired crop, Douglas-fir.

Douglas-fir trees debarked by voles did not exhibit differences in 2-year average growth rates when comparing the periods 1980-1981 and 1982-1983. In addition, there were no significant differences in growth rates among severely damaged, moderately damaged and undamaged trees. Therefore, an economic loss cannot be demonstrated from this preliminary assessment. Observations of vole feeding scars are insufficient to conclude that damage is economically important. However, the impact of feeding by voles on trees may not be evident for several growing seasons. There was some tree mortality on Texada Island, but it was difficult to determine when these trees were damaged and what percentage of debarking was inflicted to cause mortality or growth abnormalities. Another consideration in evaluating long-term impacts of vole damage is secondary pests which may compound the problem and promote tree mortality. The debarking scars initiated by voles may serve as entry ports for disease and insects or cause mortality by weakening the trees' resistance to "blow down" and "snow press". Decay resulting from wounds due to logging, fire and thinning is economically significant (Etheridge 1978, Harrington et al. 1983). Hence, vole damage, although not significant yet, may alter form and reduce growth and survival of trees when compounded by secondary pests.

Since no economic loss to forest productivity is now evident control measures are currently unnecessary. In anticipation of delayed impacts, the damaged areas should be reexamined in 5 to 10 years to determine whether reductions in volume are evident and whether they represent an 
economic loss over the long term. Also, spot checks through juvenile spacing blocks on Texada Island should be repeated annually to detect new or enlarging areas of damage. If damage does increase and becomes economically significant, knowledge of the population density of voles and the annual and inter-annual fluctuations would be important. Population monitoring would indicate when interventions for control of voles would be most effective (Sullivan and Sullivan 1982).

\section{Acknowledgements}

R. Diprose assisted with the field work. B. Nyberg and J. Borden gave advice and criticism. The BC Ministry of Forests provided financial support.

\section{References}

Avery, T.E. 1967. Forest Measurements. Chapter 12: 208-225. McGraw Hill Book Co. New York.

Birney, E.C., W.E. Grant and D.D. Baird. 1976. Importance of vegetative cover to cycles of Microtus populations. Ecology 57 : 1043-1051.

Buckner, C.H. 1972. The strategy for controlling rodent damage to pines in the Canadian mid-west. Proc. Vert. Pest Conf 5: 53-48.

Campbell, T.E. 1976. Bird and mammal problems in southwestern pine forests. Proc. Vert. Pest Conf. 7: 229-234.

Canutt, P.R. 1969. Relative damage by small mammals to reforestation in Washington and Oregon. In: Black, H.C. (ed). Proc. Symp. Wildlife and Reforestation in the Pacific Northwest. Oregon State Univ., Corvallis. p. 55-59.

Dimock, E.J. 1971. Assessment of animal damage in the Pacific Northwest forests - a problem analysis and short term program of research. USDA For. Serv. Gen. Tech. Rep. Pacific Northwest Forest and Range Experiment Station, Portland, Oregon. $12 \mathrm{p}$

Etheridge, D.E. 1978. Wound parasites causing tree decay in British Columbia. Can. For. Serv., Pac. For Res. Cent. Pest Leaflet No. $62.15 \mathrm{p}$.

Green, J.E. 1978. Techniques for the control of small mammal damage to plants: a review. Alberta Oil Sands Environmental Research Program Report 38: $111 \mathrm{p}$.

Harrington, C.A., C. Reinhart, D.A. Thormburg and F.W. Cobb. 1983. Association of black-stain root disease with precommercial thinning of Douglas-fir. For. Sci. 29: 12-14.

Howard, D. 1982. Wildlife damage to forests in the Vancouver forest region. BC Min. For., Res. Br. WHR-3,21 p.

Klinka, K., F.C. Nuszdorfer and L. Skoda. 1979. Biogeoclimatic units of central and southern Vancouver Island. BC Min. For. $120 \mathrm{p}$.

Krebs, C.J. 1979. Dispersal, spacing behaviour, and genetics in relation to population fluctuations in the vole, Microtus townsendii. Can. J. Zool. 25: 61-67.

Martell, A.M. and A. Radvanyi. 1976. Changes in small mammal populations after clearcutting in northern Ontario's Black Spruce forest. Can. Field-Nat. 91: 412-416.

Sullivan, T.P. 1984. Effects of snowshoe hare damage on juvenile lodgepole pine-implications for spacing natural stands. BC Min. For. Res. Note 94:27 p.

Sullivan, T.P. and D.S. Sullivan. 1982. Barking damage by snowshoe hares and red squirrels in lodgepole pine stands in central British Columbia. Can. J. For. Res. 12: 443-448.

USDA Forest Service. 1968. Animal Damage Control Handbook. USDA For. Serv. Rep. 6., FSH 2609-22R6

Warnock, J.E. 1965. The effects of crowding on the survival of meadow voles (Microtus pennsy/vanicus) deprived of cover and water. Ecology 46: 649-664

\section{RESEARCH ASSOCIATE University of Victoria}

Research Associate wanted to carry out detailed anatomical and developmental studies of conifer seedlings. Ph.D in conifer developmental biology required. Starting salary $\$ 1864$ per mo. Earliest starting date October 1986. Send applications and CT to: Dr. John N. Owens, Biology Department, University of Victoria, Victoria, B.C. V8W 2 Y2. 